\title{
COMMUNICATIVE ACTS IN THE TEXTS OF THE NEW TESTAMENT GOSPELS: MENTAL AND AXIOLOGICAL, MORAL AND ETHICAL FACTORS
}

\author{
YAROSLAV MELNYK
}

\begin{abstract}
The key issue of the article is the typology of communicative acts in the texts of the New Testament; the communicative acts are discussed from mental and axiological, moral and ethical perspectives. The goal of the article is to establish, discuss and interpret the main parameters of communication between Christ, His followers and opponents. The accent is made on the components of Christian world view as a discourse factor in the New Testament's texts.

The analysis results are extrapolated to the sphere of discourse creation, its linguistic, philosophical, ethical and communicative aspects. The principles of human existence and the existence of information space in the early $21^{\text {st }}$ century are discussed.
\end{abstract}

Keywords: communication, communicative behavior, moral and ethical factors, text, ethnoculture.

Within the last decades, the issues of discourse, communicative acts, social and ethical scenarios of communication and general discourse have significantly increased in importance [9, p. 20]. It is but natural, taking into account the advancement in the spheres of information technologies, communication systems, the World Wide Web, communication ethics, various information services, types and means of computing and transferring information. The beginning of the $21^{\text {st }}$ century is marked by an unprecedented and overwhelming spread of telecommunication services - television, radio, the Internet, press. As a result, a number of problems related to communication systems and the culture of communication can no longer be regarded as local ones; now they are classified as urgent issues. Such problems are mostly discussed and interpreted in the contexts of human ecology, cultural ecology, philosophical anthropology [10, p. 36]. They are core topics in the works of world's linguists, jurists, psychologists, social scientists, philosophers. Most of the researchers, in this or that way, point out the need for systemic and intensive study of the nature of cultural and information space [7, p. 194].

In this article, I am not going to do any close analysis of religious, cultural, economic, ideological, moral, ethical or any other factors in ancient Judean society (or society in general); even a brief analysis of the epoch of Jesus Christ clearly indicates one key issue: all the intentions of the Messiah, His aspirations and endeavors are aimed at exposing spiritual vices of the contemporary cultural and social model. These are what Christ sees as the greatest danger, threat, challenge to society as a system and to all humanity. It means that not thieves, robbers, murderers or any other suchlike criminals pose the greatest threat to society; it is not them that the Lord's messenger constantly opposes. He fights with the teachers of the law (the scribes) and the Pharisees, hypocrites, false and sly prophets, tax collectors 
(publicans), sinners, representatives of other related categories. It is a kind of implicature, the index of His communicative behavior. In the texts of the New Testament Gospels, there is a detailed analysis of a wide range of human vices; and in each particular case, Christ calls people to repent, to fill their souls with virtues, to turn their lives to the course of God's commandments.

The activity of Christ should be considered not only from the perspective of sociology, theology or philosophy, but also as a type of communicative behavior, a communicative and informational model. We can assume that moral and ethical, mental and axiological categories condemned by Christ (in the texts of the New Testament Gospels) are associated with universal evil that has to be defeated, excluded from the conceptual picture of the world.

The whole text of the New Testament is focused on the assessment, analysis and interpretation of mental and communicative, intellectual and behavioral patterns of the chief priests (the high priests), the teachers of the law and the Pharisees; against them Christ and His followers wage an irreconcilable struggle. Their mentality, immoral communicative behavior, idiolect are in the focus of attention. It is in them that the adherents of the new faith see the greatest threat to humanity. Thus communicative behavior is emphasized and placed in the center of the narrative system of the whole New Testament. Here communication is regarded as a form of self-realization, the space of Being, an inalienable condition of human existence [12, p. 128].

If we turn to the texts of the New Testament Gospels, pick out the above categories and consider them in the context of new semantic and semiotic theories (for example, the theory of semantic fields), we will receive an isometric/holographic picture, in which these categories are presented in all their complexity; it enables us to analyze and interpret them, to establish their basic determinants, functions, relations.

In lexicographic (and other) sources, the Pharisees are defined as a community or sect, whose members were known for their hypocrisy and pride [11, vol. II, p. 231] (here and below all the citations, except for those from the Bible's texts, are translated from Ukrainian). Their other characteristic feature was moral formalism, which manifested itself in rigorous, outwardly formal or ostentatious observance of moral rules... [6, 82-83]. In the texts of the New Testament, much attention is given to the communicative behavior of the Pharisees, who are often presented as Christ's opponents.

The Pharisees, as well as the teachers of the law and the chief priests, are hypocrites, bearers of the worst human qualities, who ostentatiously demonstrate their religious belonging, whose imitation of true religious feelings, outward entourage and mummery are used to mask their insincerity, meanness, mendacity. Jesus addresses the Pharisees and the teachers of the law, "You brood of vipers, how can you who are evil say anything good? For the mouth speaks what the heart is full of. ... But I tell you that everyone will have to give account on the day of judgment for every empty word they have spoken" (Matthew 12:34-36) [15]; [12, p. 22]. An inalienable feature of the Pharisees' nature is craftiness. This ethical, linguistic, sociocultural and narratological category is defined as the discrepancy between words/actions and one's true convictions (sin) [4, p. 488; 7, p. 200; 13, p. 79]. It is inclination towards using outwardly right, pretentiously truthful/sincere words (texts) that mask falsehood, insincerity, hidden deception, manipulation. Jesus says to the teachers of the law and the Pharisees, "A wicked and adulterous generation asks for a sign! But none will be given it ..." (Matthew 12:39) [15]; [12, p. 22].

The communicative scenarios of the Pharisees and the teachers of the law involve pretentious righteousness, simulated sincerity and feigned adherence to religious canons, while their thoughts, actions, ambitions, pragmatics are directly opposite. Christ says, "What goes into someone's mouth does not defile them, but what comes out of their mouth, that is what defiles them". Then the disciples came to him and asked, "Do you know that the Pharisees were offended when they heard this?" He replied, "Every plant that my heavenly Father has not planted will be pulled up by the roots. Leave them; they are blind guides. If the blind leads the blind, both will fall into a pit" (Matthew 15:11-14) [15]; [12, p. 27]. Jesus also says, " ... the things that come out of a person's mouth come from the heart, and these defile them. For out of the heart come evil thoughts" (Matthew 15:18) [15].

Christ keeps warning His disciples and all those who listen to Him and urges them to beware of the words (texts) of the Pharisees (as well as those of the Sadducees, the teachers of the law, false prophets 
and suchlike) because their words cannot be trusted, their speech is deceitful; they divert the thoughts, the hearing and the hearts of their listeners from the truth; they spin a web of deception to misdirect the minds of those who listen to them, so that a person cannot tell the right from the wrong. Then they understood that he was not telling them to guard against the yeast used in bread, but against the teaching of the Pharisees and Sadducees (Matthew 16:12) [15]. In the texts of the New Testament Gospels, we find the definition of the Pharisees (and the teachers of the law): "... for they do not practice what they preach" (Matthew 23:3) [15]; it emphasizes their duplicity, utter discrepancy between their words and actions; their words count for nothing, while their pragmatics, materialism, self-interest are obvious because Everything they do is done for people to see ...; they love the place of honor at banquets and the most important seats in the synagogues ..." (Matthew 23:5,6) [15]; [12, p. 39]. Further in the text, Christ speaks directly to the Pharisees; His words are highly emotional, "Woe to you, scribes and Pharisees, hypocrites! For you devour widows' houses, and for a pretense make long prayer..." (Matthew 23:14) [15]. In His parables, Jesus gives a most vivid interpretation of the depravity of the Pharisees' hypocritical philosophy, reveals their apostasy, their lawless and unethical ways (duplicity), "Woe to you, teachers of the law and Pharisees, you hypocrites! You give a tenth of your spices... But you have neglected the more important matters of the law justice, mercy and faithfulness.... You clean the outside of the cup and dish, but inside they are full of greed and self-indulgence" (Matthew 23:23, 25) [15]; [12, p. 40]. In this way, Christ emphasizes that not only outward form has to be perfect, but the content has to correspond to the form and the message, i.e. it has to be pure, perfect, "Blind Pharisee! First clean the inside of the cup and dish, and then the outside also will be clean" (Matthew 23:26) [15]; [12, p. 400]. "In the same way, on the outside you appear to people as righteous but on the inside you are full of hypocrisy and wickedness" (Matthew 23:28) [15]. The Pharisees' behavior (as well as that of the teachers of the law and the chief priests) clearly indicates that for them, social and material status comes before faith. When it comes to the matter of social status, they would stop at nothing, be it hypocrisy, guile or something else. According to Jesus Christ, they pose the greatest threat to religion and society. The words of the truth, the exposure of their true nature fill them with great indignation; they oppose Christ aiming at Him the spear of their rage, hatred, antagonism. Consider the story of Jesus healing a man with a withered hand: being aware of their helplessness, spiritual and religious insolvency, inferiority, they plot to murder Christ because for them, it is the only way to avoid defeat and public shame, Then the Pharisees went out and began to plot with the Herodians how they might kill Jesus (Mark 3:6) [15]; [12, p. 55].

Another typical form of the Pharisees' communicative behavior is slander. When their plans and intentions are revealed and publicly criticized, they resort to trickery; most often, they use slander, gossip and other kinds of disinformation. Such forms of communicative behavior are a distinctive characteristic of this category of Christ's opponents [3, 490-491].

Most often, Christ calls the Pharisees hypocrites because their words and thoughts/actions usually diverge; their language, speech (all types of communicative behavior), words perform an exclusively imitative function. For instance, in answer to their reproach concerning washing one's hands before a meal, Christ says that one can take care of the cleanness of their hands, but neglect their soul. Having clean hands before a meal is important, but a person's conscience should be their prime concern, "What comes out of a person is what defiles them. For it is from within, out of a person's heart, that evil thoughts come sexual immorality, theft, murder, adultery, greed, malice, deceit, lewdness, envy, slander, arrogance and folly. All these evils come from inside and defile a person" (Mark 7: 20-23) [15]; [12, p. 62].

The Pharisees, together with the teachers of the law, often probe Jesus. They listen fastidiously to his words in order to catch Him at making mistakes, errors, being inaccurate or diverging from the canons of the Jewish religion, while Christ is not an opponent of faith itself; He just opposes duplicity, insincerity, whatever is false in behavior, prayers, communication and rituals. But His critics blame Christ for His alleged apostasy, departure from the Jewish traditions, violation of the law. The truth of Christ's felicitous remarks (proverbial labels), parables and perfect formulas is so obvious that it cannot be doubted, Later they sent some of the Pharisees and Herodians to Jesus to catch him in his words.... But Jesus knew their hypocrisy. "Why are you trying to trap me?" he asked. "Bring me a denarius and let me look at it" (Mark 12:13, 15) [15]; [12, p. 71]. 
Meticulous observance of the form of the rituals commonly accepted in the Israel of that time is a characteristic feature of the Pharisees' behavior. But their orthodoxy in rituals, as well as in other social and communicative actions, is feigned, insincere. For instance, in the $6^{\text {th }}$ chapter of the Gospel of Luke, it is said that the Pharisees accuse Jesus and His disciples of ignoring the Sabbath because going through the grain fields, the latter have picked some heads of grain. In response, Christ reminds them of the story of David, thus arguing that it is not a sin to do what has to be done, to work on a holy day $[12,90]$. Preaching on the Mount of Olives, Christ speaks of vanity of the Pharisees and the teachers of the law. He exposes their desire for an honor that they do not deserve, "Woe to you when everyone speaks well of you, for that is how their ancestors treated the false prophets ..." (Luke 6:26) [15]; [12, p. 91].

As to the discourse of the Pharisees and the teachers of the law, the hypocrisy and the manipulative nature of their preaching are well masked: these features are concealed, disguised as sincerity and genuineness; and this guile presents the greatest danger. No doubt, the falseness of their words will be revealed and condemned. Yet the problem is that, being spread around, it enters human consciousness, slithers into discourse, weaves itself craftily into the linguistic picture of the world and becomes a norm, an inalienable element of existence. Christ says, "Be on your guard against the yeast of the Pharisees, which is hypocrisy. There is nothing concealed that will not be disclosed, or hidden that will not be made known" (Luke 12:1-2) [15]; [12, p. 104].

Jesus' arguments defeat the Pharisees, the teachers of the law, the experts in the law, the ministers of the Jewish faith, those who care only about the formal side of the rituals. Ingenious as they are in their search for arguments to justify their ways, they fail to refute Christ. In the Gospel of Luke, it is said, ... One Sabbath, when Jesus went to eat in the house of a prominent Pharisee, he was being carefully watched. ... Jesus asked the Pharisees and experts in the law, "Is it lawful to heal on the Sabbath or not?" ... Then he asked them, "If one of you has a child or an ox that falls into a well on the Sabbath day, will you not immediately pull it out?" And they had nothing to say (Luke 14:1, 3, 5) [15]; [12, p. 108].

The Pharisees, the teachers of the law and the chief priests are the most radical opponents of Christ. Tax collectors, sinners and common people listen to His words, while the Pharisees remain steadfast and irreconcilable in their position. Unable to stand against the force of His arguments, they are always defeated in dialogues with Christ. When they reproach Christ for receiving sinners, having a meal, drinking wine and sitting at the table with them (according to an old Jewish tradition, "sitting at the table" implies a high degree of trust and respect), which was not acceptable in ancient Israel, Jesus reminds them of the parable of the lost sheep [12, p. 110].

Material values and social status are the dominant elements in the axiological system of the Pharisees, though they claim they are called to serve God, to be pure and sincere before Him. Such dualism, the split between mental and communicative patterns, on the one hand, and social behavior, on the other, is their characteristic feature. Consider the following: The Pharisees, who loved money, heard all this and were sneering at Jesus. He said to them, "You are the ones who justify yourselves in the eyes of others, but God knows your hearts. ..." (Luke 16:14-15) [15]. Thus according to Christ, the truth is above all and one day, these "servants of God" will have to answer for their hypocrisy. The Pharisees' attempts at discrediting Christ end in utter fiasco, while the authority of Jesus is ever more obvious and widely recognized. Christ (as Solomon before Him) always finds an effective and successful strategy to win the battle against the infidel. Consider, for example, the parable of a woman who lived a sinful life. With a single short utterance, Christ disarms an aggressive mob; His words "Let any one of you who is without sin be the first to throw a stone at her" (John 8:7) [15]; [12, p. 141] have become a unique formula, an aphorism.

The common people of Judaea, so called people in the street are easy to manipulate. Here "manipulation" is regarded as exercising control over others; influencing others, addressees; suitably directing their intentions; as a conscious and purposeful action [14, p. 12-13]. Sometimes, common people are able to see the truth: they greet Christ, follow Him, listen to Him and admit the truthfulness of His words. But they are weak and confused. They are an easy target for the Pharisees, the teachers of the law, the experts in the law, who use various manipulative strategies; brute force wins, the truth is defeated. The high wisdom and the truth become vulnerable, easily hurt, unable to defend themselves; 
and evil wins. It is most vividly described in the part of the Holy Scripture that tells about Christ's entry into Jerusalem. Most of the citizens hail Him as the Messiah, cut branches from the palm trees and spread them on the road (Palm Sunday). He is the winner, the hero, the person of the highest authority. It is only several days later that the same people led by the chief priests go to Pontius Pilate and demand His execution [12, p. 147].

It is evident from the texts of the New Testament that the chief priests and the teachers of the law also are in opposition to Jesus Christ. From a semiotic perspective, they are in one row with the Pharisees, tax collectors, false prophets, sinners. Their social and religious status is somewhat higher, their role in the rituals is more important, but their mental and communicative behavior patterns are similar to those of the Pharisees. Moreover, there is similarity between the chief priests, the teachers of the law and the other categories of those in opposition to Christ not only in behavioral and communication models, but also in mental, axiological and ideological, social patterns and scenarios. As a matter of fact, they form a united front against Jesus, adopt a unified strategy of attack. The New Testament provides plentiful evidence of it:... some Pharisees and teachers of the law came to Jesus from Jerusalem ... (Matthew 15:1); The next day, the one after Preparation Day, the chief priests and the Pharisees went to Pilate (Matthew 27:1); "... do not be like the hypocrites..." (Matthew 6:5); "Watch out for false prophets...." (Matthew 7:15); "You of little faith,..." (Matthew 8:26); "many tax collectors and sinners came" (Matthew 9:10); "Here is a glutton and a drunkard, a friend of tax collectors and sinners" (Matthew 11:19); "...You brood of vipers, how can you who are evil say anything good? ..." (Matthew 12:34); "... That is how it will be with this wicked generation" (Matthew 12:45); The Pharisees and Sadducees came to Jesus (Matthew $16: 1) ; . .$. suffer many things at the hands of the elders, the chief priests and the teachers of the law ... (Matthew 16:21) and others [15]. It means that the Pharisees, the teachers of the law, the chief priests, tax collectors, false prophets, sinners, the sly, hypocrites form a united opposition to Jesus Christ. Thus the teachers of the law and the chief priests are close, yet different, religious and social categories. The teachers of the law (the scribes) are "the class of persons who devote themselves to the study and the interpretation of Judaic law", "the experts in the law" [5, p. 255; 11, vol. II, p. 265-288], while the chief priests are chief religious officials, priest guides; in the time of Jesus Christ, these positions were occupied by highly immoral and sinful individuals. One such was the Chief Priest Caiaphas [11, vol. II, p. 66].

It should be noted that Christ uses the word hypocrites as a collective name for such persons. The teachers of the law and the chief priests, who are supposed to be the model of virtues, demonstrate hypocrisy and elaborate pretence, feigned virtues, feigned honesty, feigned sincerity and faith, false prayers, false public declaration of devotion to religious ideals, tricks, deceit, avarice and jealousy. There is only one possible way, that of catharsis, to get rid of hypocrisy and to become sincere in one's thoughts and actions because even in their repentance and prayers to God, the Pharisees and the teachers of the law lack sincerity of expression and purity of hearts.

The teachers of the law, the Pharisees and the chief priests form a social and cultural unity. They demonstrate the same type of communicative behavior. Their camouflage, pretence, play to the gallery, feigned righteousness and sincerity, their hypocrisy destroy the spiritual and cultural achievements of the previous generations, invalidate the teachings of the Prophets, the fundamental law of the state, economic, cultural and spiritual systems. Their hypocrisy is obvious; it is the dominant feature of mentality and communicative behavior of Christ's opponents. He sees the flexibility of deceit, its complexity and adaptive potential, and He says, "So when you give to the needy, do not announce it with trumpets, as the hypocrites do in the synagogues and on the streets, to be honored by others..." (Matthew 6:2) [15]; [12, p. 11]. He urges people to be modest, polite in their communicative behavior. It is in this that the truth lies, not in showing off or publicly demonstrating one's beneficence; such behavior is sinful and has nothing to do with true beneficence and the service to God [6, p. 89]; [13, p. 79].

Sometimes, tax collectors and some other opponents of Christ see His undeniable superiority, they leave their co-religionists to follow Christ; in the New Testament it is said, Then a teacher of the law came to him and said, "Teacher, I will follow you wherever you go" (Matthew 8:19) [15]; [12, p. 15]. In some cases, the Pharisees, the teachers of the law, tax collectors, being unable to defeat the truth of Christ's words, 
admit His righteousness and virtue; then they call Him Teacher. In the Judea of that time, it was one of the highest titles. Christ, in His turn, urges them to work on themselves, to keep purifying their souls and getting rid of hypocrisy. In some cases, He calls them a faithless and perverse generation (Luke 9:41) [16], a wicked and adulterous generation (Matthew 16:4), you hypocrites (Matthew 22:18) [15], thus urging them to fully clean themselves from hypocrisy because it is not enough to join Christ, to accept His ideas and to admit the righteousness of His words and actions. Becoming Christ's associate is a process, the process of purification, catharsis, strengthening one's faith. He addresses them and calls for new ethics and new morality, "Woe to you, teachers of the law and Pharisees, you hypocrites! You give a tenth of your spices-mint, dill and cumin. But you have neglected the more important matters of the law-justice, mercy and faithfulness. ..." (Matthew 23:23) [15]. A material contribution is not enough, one should make a spiritual contribution too.

The opposition between the two models, two conceptual pictures of the world, which exposes double thinking, duplicity, treachery of the opponents of Christ, culminates in the events of Palm Sunday, Judas' betrayal, the crowd's demand to release Barabbas and to execute Christ. Not Barabbas, a robber and murderer, is a threat to the Israelites, but Christ, who calls for mercy, charity, spiritual purity, sincerity, love. In this the Israelites see a threat and the destruction of the foundations of the state and faith. Christ wins victory in the fight with the teachers of the law and the Pharisees, and His enemies are defeated and shamed. They adhere to the letter of the law - as they always declare, while Christ in His monologues suggests new rules of existence, a new law based not on formal observance of religious rules, but on love. This is a new model of philosophical and religious doctrines, a new model of verbal and communicative behavior. That is why the parables and other fragments of the Gospel's text are more than apologias for the new faith; they are principal elements of the new law of being, the new ethics and morality.

Christ uses comparisons, metaphors and other tropes, creates parables and very short stories of great illocutionary force and perfect form, content and composition; this is a distinctive feature of His speech, a strategy ensuring maximum effect. His communicative acts disarm His opponents and reveal their true nature. It has been said above that, being constantly defeated in verbal duels, the chief priests, the teachers of the law and the Pharisees resort to a radical form of opposition, physical destruction. ...The chief priests and the teachers of the law heard this and began looking for a way to kill him, for they feared him, because the whole crowd was amazed at his teaching (Mark 11:18) [15]; [12, p. 70]. Christ often stresses that the prescriptions of the experts in the law can poison the information environment, that their words cannot heal, they do not lead to spiritual salvation; quite the opposite, they are the root of total, universal evil; He warns people against the teachers of the law and their edification. The Bible says, The large crowd listened to him with delight (Mark 12:37) [15].

The chief priests and the teachers of the law hand Christ over to Pilate the governor and aggressively demand for His execution, thus committing the greatest act of cynicism. The procurator Pontius Pilate finds no crime in Jesus and intends to release Him; but he gives up under the pressure of the crowd; to avoid turmoil and riot, he orders to release Barabbas and to execute Christ. The chief priests are fully aware of the rising authority and the invincibility of Christ; their jealousy and fear of losing authority among the citizens of Judea are the main factors behind their decision and the motivation for their behavior. The social authority of Christ keeps growing, His teachings being the "global wisdom", the universal formulas of behavior. Pilate says, ... "Do you want me to release to you the king of the Jews?" (Mark 15:9); being jealous, the chief priests "... stirred up the crowd to have Pilate release Barabbas instead" (Mark 15:11) [15]; [12, p. 77]. In order to utterly destroy Christ, both physically and morally, they mock Him when He is dying on the cross and ask Him why He cannot save Himself.

The teachers of the law, the Pharisees and the chief priests blame Jesus for ignoring the text of the law, the traditions and rituals. Disrespect for God was a great sin in the Judea of that time. But the analysis of their communicative behavior and context-specific discourse analysis show that the opponents of Christ are deceitful, false witnesses. For them, religion, faith, rituals, temples are a convenient environment, the means of survival, the condition of their existence, their comfort zone. 
Christ opposes them, saying, "My house will be a house of prayer ..." (Luke 19:46) [15]; it explains His symbolic act of driving the sellers out of the temple court.

Tax collectors, like the chief priests, the teachers of the law and the Pharisees, also are the opponents of Jesus. From the perspective of religious studies, linguistic and cultural studies, social studies, their belonging to the opposition is somewhat surprising and illogical. In the economic, ethnic, cultural and state systems of ancient Israel and Rome, there were dozens, hundreds of other similar (even equal at first glance) occupations, positions, types of activity that formed a holistic state and economic model. But the Israel of Christ's time (at the beginning of our era) should be regarded as a unique, self-sufficient, internally ordered hierarchical system, in which tax collectors had a specific role and were a category apart. At that time, Israel was a province of the Roman Empire. For the Roman State, the effective uninterrupted process of tax collection in the provinces was a matter of primary importance. But tax collection by Romans themselves was ineffective. Jewish tax collectors were much more efficient: the local population could hardly hide any valuables or any activity from their countrymen. Moreover, Jewish tax collectors, who filled the treasury of the Roman Empire, had personal "benefits", chances for personal enrichment. Tax collectors hired from the local population and the system of taxes itself were a hard burden for the people of the lands of Israel. In the eyes of common people, a tax collector was nothing but a traitor, a person of low morality, who has no dignity, does not deserve any respect, a wicked person possessed by greed, a chrysophilist [5, p. 322]. There was a whole army of tax collectors in Judea; there were even more people wanted to get this position; but the Roman system of taxation did not need so many collectors of revenue. So there were a great number of Jewish people who were ready to betray their fatherland, to serve the conquerors, to benefit from the poverty and misery of their countrymen. The number of those for whom the choice between conscience and money was an easy one, who were ready to collect taxes from their own kin (often, it was a sheer robbery) was great. Quite a lot of Christ's countrymen had no moral scruples about it. That is why in the texts of the New Testament Gospels, tax collectors also are the focus for antagonism, struggle, strife. Often, they become the symbol of treachery, guile, wickedness, meanness, greed, sin and moral degradation. From Christ's lips, the word tax collector sounds like traitor, sneak. Tax collectors stand in one row with sinners, men of little faith, the Pharisees and others. Though unlike the chief priests, tax collectors are not a hopeless social category. Sometimes, Jesus has a meal with them, talks to them, involves them in discussions. In the texts of the New Testament Gospels, the tax collector is a bundle of negative features; but he may be directed in the right way, While Jesus was having dinner at Matthew's house, many tax collectors and sinners came and ate with him and his disciples (Matthew 9:10) [15]; [12, p. 16].

Christ shows mercy, patience, tolerance towards tax collectors; they are not so dogmatic as, for instance, the teachers of the law and the chief priests (though even to the latter He is ready to show mercy; He believes in the possibility of guiding them into the truth). According to Christ, they just suffer from spiritual illnesses, but these illnesses are curable. That is why He often calls for repentance, spiritual cleansing. In some cases, tax collectors (unlike the teachers of the law) quit and join Christ's faith: ... All the people, even the tax collectors, when they heard Jesus' words, acknowledged that God's way was right, because they had been baptized by John (Luke 7:29) [15]; [1, p. 1273]; " ...The Pharisee stood by himself and prayed: 'God, I thank you that I am not like other people-robbers, evildoers, adulterers - or even like this tax collector...' ... But the tax collector stood at a distance. He would not even look up to heaven, but beat his breast and said, 'God, have mercy on me, a sinner'...' (Luke 18:11, 13) [15]; [1, p. 1294].

Those of little faith also are in opposition to Christ. He uses this nominative unit to designate almost all people around Him, even His disciples reproaching them for the weakness in the spirit and the lack of faith [1, p. 1206]. Other nominative units used in the texts of the Bible are the teachers of the law, the experts in the law, false prophets, slaves, brood of vipers, the greedy. These categories are united in a systemic opposition to the new ethics, morality, religion brought by Christ. In addition to hypocrisy and wickedness, their characteristics are cynicism, pride, jealousy, contempt for God, greed, treacherousness, duplicity, slander and disapproval, idle talk, false pathos, and spiritual squalor. Jesus Christ's earthly path is the struggle against these maladies; His teachings suggest fundamental changes 
in one's moral, ethical and communicative constitution, in the models of one's behavior. He says "... And when you pray, do not keep on babbling like pagans, for they think they will be heard because of their many words ..." (Matthew 6:7) [15]; [12, p. 11].

Among those who oppose Christ, there also are slaves. This category requires a particular discussion. In the texts of the New Testament Gospels, slaves in are divided into two distinct groups. On the one hand, they are associated with low social status, actions that deserve contempt and scorn, low morality, low and petty intentions, the absence of any social and cultural programs, degradation; slaves are statistical units of little value and importance. On the other hand, they are the symbol of obedience, politeness, loyalty; they accept the dominance of God and faithfully serve Him (a servant of God). In each particular case where the Bible speaks of a male or a female slave, slaves or slavery, we should specify the type to which the nominative unit in question belongs, its features, role and function in the whole discourse. The slave as a sociocultural and mental phenomenon is an inherent element of the texts of the Old and the New Testaments. Christ rejects the social, ideological and communicative model under which slaves are associated with low morality and believed to be bad, treacherous, deceitful, sly and inferior. On the other hand, it is an honor to be a faithful slave (servant), God's slave; this status deserves respect [12, p. 42-43]. Similarly, the social, mental, cultural and historical category represented by the linguistic items king, kingdom, kings, reign, king's is of dual semantic nature. In some particular cases, king involves the following meanings: the leader of the state; a respected, virtuous, revered, noble person; the leader of the system; a person in authority; full of wisdom; high-quality. Or it may contain meanings such as careerist, afraid of losing status and power, hyper-ambitious, the one who manipulates masses, power-thirsty, materialist, cruel to one's subordinates (for example, the King of Heaven, Solomon, King Herod). Accordingly, the social/verbal model of behavior, intentions, actions, the degree of responsibility may be placed anywhere along the scale ranging from maximum positive to maximum negative.

Jealousy as a moral and ethical category and a feature of social and communicative behavior should also be discussed [4, p. 298]. In the texts of the Holy Scripture, it is not a popular notion and the term is not often used. Christ seldom addresses this category, but it is necessarily present as a component of the conceptual picture of the world (and, correspondingly, the model of behavior). In biblical discourse, jealousy (as an ethical and psychological category) is presented as an illness, a kind of moral and psychological complex, social and mental tumor that becomes active at the personal and collective levels, turns into a tradition, fills spiritual and cultural space, weaves its way to mentality at all social levels, becomes a component of the picture of the world. Jealousy ("an envious eye") is a marked characteristic of all the opponents of Jesus, their permanent psychological and emotional state, an element of their idiolect, a canonized form of the Pharisees' consciousness and behavior, something they would not talk about or disapprove of. Calling His opponents hypocrites, a wicked generation, etc., Christ also implies their jealousy because this feeling is a form of spiritual malady, both being destructive. Jealousy should be fought as a dreaded disease, it should be rooted out from a person's heart (consider the tale of Cain and Abel) [1, p. 11].

Thus the analysis of the Gospel's discourse, of ethnic, cultural, social, pragmatic and axiological factors in its communicative acts shows the latter's typological variety that explicates a multi-layered, hierarchical structure of the spiritual and ideological picture of the ancient Jews. This picture of the world is systemic in nature, with the clearly identifiable nucleus, the peripheral and transition zones. Its epicenter is the conflict between the social, cultural, ideological and axiological complex, as embodied in the ancient Jewish tradition, and a distinctly new form of morality, ethics, the system of values, the conceptual picture of the world represented by Jesus Christ.

The truth of the teachings of the Old and the New Testaments and their complete prescriptive consistency are beyond doubt. They have established a basic program for the whole human race: the urgent need for the change in priority patterns, the correction of discourse, the introduction of new ethical and moral principles, a complete reconstruction of information space, the reorganization of the conceptual picture of the world, which should be centered around love and high moral values. These are the necessary conditions for the survival of humanity. 


\section{REFERENCES}

[1] Біблія, або Книга Святого Письма Старого і Нового Заповіту. Видання Московського патріархату, Москва, 1988.

[Bibliia, abo Knyha Sviatoho Pysma Staroho i Novoho Zapovitu. Vydannia Moskovskoho patriarkhatu, Moskva, 1986.]

[2] Бурячок А.А., Гнатюк Г.М. та ін. Словник синонімів украйнської мови: у 2-x m. Накова думка, Киӥв, 1999-2000.

[Buriachok A.A., Hnatiuk H.M. et. al. Slovnyk synonimiv ukrainskoi movy: u 2-kh t. Nakova dumka, Kyiv, 1999-2000.]

[3] Архімандрит В. Біблейська історіл. Товариство пам'яті ігумені Таїси, Санкт-Петербург, 2011. [Arkhimandryt V. Bibleiska istoriia. Tovarystvo pamiati ihumeni Taisy, Sankt Peterburg, 2011.]

[4] Великий тлумачний словник сучасної украйнської мови. Бусел В.Т. (Ред.). Перун, Ірпінь, 2004. [Velykyi tlumachnyi slovnyk suchasnoi ukrainskoi movy. Busel V.T. (Ed.). Perun, Irpin, 2004.]

[5] Дьяченко Г. Полный Церковно-славянский словарь. Изд. отдел Моск. патриархата, Москва, 1993. [Diachenko G. Polnyy Tserkovno-slavyanskiy slovar. Izd. otdel Mosk. Patriarkhata, Moskva, 1993.]

[6] Єрушевич Г.Д., Мельник Я.Г. Аогіка та етика (досвід тематичного упорядкування традиційних словників). Симфонія форте, Івано-Франківськ, 2016.

[Yerushevych H.D., Melnyk Ya.H. Lohika ta etyka (dosvid tematychnoho uporiadkuvannia tradytsiinykh slovnykiv). Symfoniia forte, Ivano-Frankivsk, 2016.]

[7] Крысько В.Г. Социиальная психология. Харвест, Минск, 2001. [Krysko V.G. Sotsialnaya psikhologiya. Kharvest, Minsk, 2001.]

[8] Левицький В.В. Семасиология. Нова книга, Винница, 2006. [Levitskiy V.V. Semasiologiya. Nova kniga, Vinnitsa, 2006.]

[9] Мельник Я.Г., Криворучко Н.В. Пролегомени до українського дискурсу: етнокультурний, політичний та лінгво-семіотичний аспекти. Вид-во Прикарпатського нац. ун-ту ім. В. Стефаника, ІваноФранківськ, 2012.

[Melnyk Ya.H., Kryvoruchko N.V. Prolehomeny do ukrainskoho dyskursu: etnokulturnyi, politychnyi ta linhvo-semiotychnyi aspekty. Vyd-vo Prykarpatskoho nats. un-tu im. V. Stefanyka, Ivano-Frankivsk, 2012.]

[10] Мечковская Н.Б. Язык и религия. Агентство “ФАИР”, Москва, 1998.

[Mechkovskaya N.B. Yazyk i religiya. Agentstvo “FAIR", Moskva, 1998.]

[11] Никифор, архимандрит. Библейская энцииклопедия. В 4 выпусках. Выпуск 1, 2. Типография А.И. Снегиревой, Москва, 1891-1892.

[Nikifor, arkhimandrit. Bibleyskaya entsiklopediya. V 4 vypuskakh. Vypusk 1, 2. Tipografiya A.I. Snegirevoy, Moskva, 1891-1892.]

[12] Новий заповіт. Гедеонові браття, 1988.

[Novyi zapovit. Gideons International, 1988.]

[13] Рождественский Ю.В. Словарь терминов. Мораль. Нравственность. Этика. Фдинта, Наука, Москва, 2002.

[Rozhdestvenskiy Yu.V. Slovar terminov. Moral. Nravstvennost. Etika. Flinta, Nauka, Moskva, 2002.]

[14] Шкіцька І.Ю. Маніпулятивні тактики позитиву: хінгвістичний аспект. Видавничий дім Дмитра Бурого, Київ, 2012.

[Shkitska I.Iu. Manipuliatyoni taktyky pozytyvu: linhvistychnyi aspekt. Vydavnychyi dim Dmytra Buroho, Kyiv, 2012.]

[15] BibleGateway. New International Version. Available at: https://www.biblegateway.com

[16] Bible Hub. Available at: http://biblehub.com/commentaries/luke/9-41.htm 
Address: Yaroslav Melnyk, Vasyl Stefanyk Precarpathian National University, 57, Shevchenko Str., IvanoFrankivsk, 76025, Ukraine.

E-mail: mel.jar@mail.ru

Received: 14.05.2018; revised: 27.08.2018.

Мельник Ярослав. Ментально-аксіологічні та морально-етичні чинники комунікативних актів у текстах Нового Заповіту. Журнал Прикарпатського університету імені Василя Стефаника, 6 (2) (2019), $119-128$.

У статті розглянуто типологію комунікативних актів у текстах Нового Заповіту з урахуванням ментально-аксіологічних та морально-етичних чинників. Виділено ключові параметри комунікації та їх інтерпретацію. Зроблено акцент на християнсько-світоглядних складниках у формуванні дискурсу євангельських текстів.

Крім цього, пропонується екстраполяція у площину сучасного лінгвофілософського та етикокомунікативного форматів дискурсотворення. Обгрунтовуються засади існування людини та інформаційного простору початку XXI століття.

Ключові слова: комунікація, комунікативна поведінка, морально-етичні чинники, текст, етнокультура. 